\title{
Toward the Development of a Scale Linking Underrepresented Engineering Faculty's Workplace Experiences \& Career Outcomes
}

\section{Dr. Jeremi S London, Virginia Tech}

Dr. Jeremi London is an Assistant Professor in the Engineering Education Department at Virginia Polytechnic Institute and State University. London is a mixed methods researcher with interests in research impact, cyberlearning, and instructional change in STEM Education. Prior to being a faculty member, London worked at the National Science Foundation, GE Healthcare, and Anheuser-Busch. She earned B.S. and M.S. degrees in Industrial Engineering, and a Ph.D. in Engineering Education from Purdue University.

\section{Dr. Stephanie G. Adams, University of Texas at Dallas}

Dr. Stephanie G. Adams is the 5th Dean of the Erik Jonsson School of Engineering and Computer Science at the University of Texas, Dallas and President of the American Society of Engineering Education (ASEE). Dr. Adams has held administrative and faculty positions at Old Dominion University, Virginia Tech, Virginia Commonwealth University and the University of Nebraska-Lincoln. Dr. Adams is an honor graduate of North Carolina A\&T State University, where she earned her BS in Mechanical Engineering. She was awarded the Master of Engineering degree in Systems Engineering from the University of Virginia and she received her Ph.D. in Interdisciplinary Engineering from Texas A\&M University, where she concentrated on Industrial Engineering and Management.

Her research interests include: Broadening Participation, Faculty and Graduate Student Development, International/Global Education, Teamwork and Team Effectiveness, and Quality Control and Management. In 2003, she received the CAREER award from the Engineering Education and Centers Division of the National Science Foundation. Dr. Adams is a leader in the advancement and inclusion of all in science, technology, engineering, and mathematics (STEM) education. She has worked with numerous of colleges and universities, government agencies and non-profit organizations on topics related to graduate education, mentoring, faculty development and diversifying STEM.

Adams is the recipient of numerous awards, including: the 2017 WEPAN Founders Award; the 2016 ASEE Engineering Management Bernie Sarchet Lifetime Award; the 2013 Alumni Achievement Award North Carolina A\&T State University; and the Holling Teaching/Advising/Mentoring Award and Henry Y. Kleinkauf Outstanding Assistant Professor Teaching Award from the University of Nebraska-Lincoln. In 2005, she was selected as an AAAS/NSF Science and Engineering Policy Fellow and in 2013, she was selected as a fellow of ASEE.

\section{Julia Machele Brisbane, Virginia Polytechnic Institute and State University}

Julia Brisbane is a Ph.D. student in the Engineering Education Department at Virginia Tech and an M.S. student in the Virginia Tech - Wake Forest University School of Biomedical Engineering and Sciences Engineering. She received her Bachelors of Science in Bioengineering from Clemson University. She was previously an undergraduate research assistant in Clemson University's Engineering and Science Education Department. Her research interests include undergraduate research experiences, diversity and inclusion in engineering, and intersectionality.

\section{Miss Crystal M. Pee, Virginia Polytechnic Institute and State University}

Crystal Pee is a graduate student at Virginia Polytechnic and State University pursuing a Ph.D. in Engineering Education. Her research interests include broadening participation in industry. Prior to attending Virginia Tech, she received a Bachelor of Science degree in Chemical Engineering with a minor in Business Administration from Clemson University. 


\title{
WIP: Toward the Development of a Scale Linking Underrepresented Engineering Faculty's Workplace Experiences \& Career Outcomes
}

\begin{abstract}
Although there has been an increase in the number of diverse students enrolling in engineering programs, the dismal progress in the representation of women, underrepresented minorities, and persons with varying abilities among College of Engineering faculty highlight the need for more work in this area. Given this problem, this project builds on this need by focusing on Black women engineering faculty-- a group that is one of the least represented among their colleagues. Their underrepresentation is partly explained by idiosyncrasies in their experiences that lead to varying career outcomes; existing literature highlights four salient factors. Using Messick's theory of instrument development as a methodological framework, the long-term goal of this study is to develop the Faculty Experiences \& Outcomes Multidimensional Scale (FEOMS)-- a valid and reliable instrument that examines the influence of mentoring, organizational climate, incivility, and perceptions of role expectations on career outcomes and jobs satisfaction among Black women faculty in engineering. The initial draft of FEOMS includes 55 items that were modifications of items in existing scales that measured these four constructs individually. This paper presents the results of a pilot study including responses from 111 survey participants. The item analysis and polychoric correlation matrix offer preliminary evidence for the content, substantive and structural validity of the instrument. Additionally, these results link existing bodies of work by revealing empirical links between these latent constructs. Next steps for gathering additional validity evidence for the FEOMS are also discussed. Ultimately, this work will contribute to a more nuanced understanding how familiar constructs are linked and has implications for broadening participation across at all levels of engineering education.
\end{abstract}

\section{Introduction}

Although the world continues to become increasingly more diverse, this diversification is not reflected among engineering faculty. Despite an increase in the number of students enrolling in engineering and in faculty hires, the dismal progress in the representation of women, underrepresented minorities, and persons with varying abilities highlight the need for more work in this area. This project builds on existing scholarship by focusing on Black women engineering faculty (BWEF)-- a group that is one of the least represented among their colleagues. Their underrepresentation is partly explained by idiosyncrasies in their experiences that lead to varying career outcomes. BWEF are less likely than men to be employed in tenure-track positions [2], earn tenure [2,3], or become a full professor [2,3]; and the findings of a recent study report perceptions of disparities in salary and awards [2]. On the other hand, the receipt of a promotion, tenure, and professional autonomy are things that have been found to contribute to the retention of BWEF [2].

Existing literature identifies four types of factors that significantly influence their experiences and career outcomes: (1) the impact of mentoring; (2) aspects of a chilly organizational climate and acts of incivility; (3) clarifying role expectations; and (4) personal attributes. (See "Constructs Overview" for additional information.) Instruments have been developed to measure each of these constructs individually, but have not been combined to understand the impact of this combination of factors on the career outcomes of BWEF. Using Messick's theory of instrument development $[9,10]$ as a methodological framework, the long-term aim of this study is to develop the Faculty Experiences \& Outcomes Multidimensional Scale (FEOMS)-- a valid and reliable instrument that examines the influence of mentoring, organizational climate, incivility, and role expectations on the career outcomes and jobs satisfaction of engineering faculty, especially women of color. FOES is a compilation of items pulled from existing instruments that measure the four aforementioned factors (e.g., [4-8]) and tweaked for studying these phenomena in an academic context. This work in progress paper presents the results of a pilot study, a first step toward this long-term goal. 


\section{Constructs Overview}

Existing scholarship includes a variety of positive, negative, and neutral factors that impact African American women engineering faculty's (BWEF) work experiences and career outcomes. They tend to be associated with four themes: 1) personal attributes; 2) mentoring; 3) role expectations; and 4) organizational climate. This review will include a synthesis of this work and provide a basis for the development of a valid instrument for empirically studying relationships between them.

Some of the personal attributes of BWEF influence the experiences they have in the workplace and their career outcomes. Studies have shown that BWEF experience slightly higher stress than other faculty $[2,3]$. Time constraints on completing activities, promotion concerns, and variations in expectations contribute to these higher stress levels; this is particularly true for women of color at four-year colleges [3]. Additionally, the findings from other studies report that BWEF tend to encounter unique challenges along the tenure track [3], and have high extended family responsibility [1]. These factors can contribute to a lower self-efficacy, which correlates to feelings of institutional fit [3]. On the other hand, perceptions of institutional fit can also be positively influenced by mentoring. Before moving on to mentoring it is worth mentioning a few other personal attributes that are reported to have a positive impact on work experiences and career outcomes. They include having personal autonomy, commitments to public service and community, and a connection with a spiritual force [2].

Apart from personal attributes, mentoring tends to come up quite often in the literature on factors that influence the experiences and outcomes of BWEF. Mentoring is a relationship between at least two people that involves the exchange of instrumental insights and psychosocial support as the individuals face unique challenges and/or explore opportunities. Among BWEF, studies show that connections to early mentorship promotes success [2]. On the other hand, the absence of mentoring is also discussed in existing scholarship. More specifically, some studies point to BWEF's perceptions of little or no support, mentoring, and sense of direction [2,3], and/or the receipt of conflicting advice from different mentors. Mentoring can mitigate some of these negative experiences. In fact, some studies have shown this mentoring has the largest and most consistent positive impact on their success [3]. Through mentorship, faculty are exposed to people that can help shape them as scholars and educators [3]. This is particularly effective when the mentors (or role models) possess characteristics with which the mentee can identify (e.g., race, gender) [3]. Some studies have found that mentoring relationships can help people overcome feelings of isolation [3]. Mentoring relationships can also provide insight on BWEF's role expectations.

Furthermore, the alignment of role expectations as presented by the leaders in an academic setting and minority faculty's understanding of them is another factor that influences BWEF's career advancement. In academia, career success is often denoted by earning a tenured status that resulted from conducted well-respected research, excelling at teaching, and/or engaging in ongoing service to one's institution and profession. Although professional autonomy is inherent in faculty roles, institutional norms and experiences beyond one's control tend to contribute to differences in how these expectations are realized in an individual's career. For example, BWEF's success may also be impeded by negative experiences in the classroom, especially those that involve majority students expressing disrespect [2,3]. More specifically, some majority students are eager to critique their minority faculty's classroom effectiveness [3], challenge their authority [3], and report concerns and critiques directly to them or his/her superior [3]. Existing studies also report that majority students perceive that minority faculty's expectations are too high or dissimilar from what their majority faculty expect of them [2]. These are examples of experiences over which minority faculty may have little control. Moreover, BWEF's success can also be hindered by institutional factors. They have reported perceived disparities in teaching assignments, space allocations, and resources as compared to their majority counterparts [2]. Compared to their colleagues, some BWEF faculty also perceive that they have greater service obligations $[1,3]$ and that research and service in the area of diversity are not valued as part of the promotion and tenure process. Ultimately, the lack of role clarity [3] and expectations to follow unwritten rules of university life $[2,3]$ contribute to BWEF's career success or 
lack thereof. An organizational climate can cultivate an environment of transparency of role expectations and inclusivity. This the last factor that will be discussed in this review.

Organizational climate is defined as the values, assumptions, traditions, rituals, implicit expectations, and norms of an institution. Studies show that BWEF perceive that chilly organizational climates breed social isolation [2,11, 12], marginalization [2,11, 12], bias [11, 12], discrimination [3], hostility [11, 12], and lack of respect from colleagues [2]. One study showed that BWEF who chose to depart from their university tend to do so because of conflicting experiences/views on selfefficacy, role clarity, and social acceptance [3]. Social acceptance and isolation can influence one's self efficacy and institutional fit [3]. Due to BWEF experiences the compound effects of the dual oppression as both a woman and a person of color [3], they typically have to convince others, mainly the majority colleagues, that they are good enough to fulfill their role as a faculty member [2]. Even though studies have not concluded whether gender or race contribute to the effects felt from a chilly organizational climate [3], addressing these contributing factors for this type of environment can have a positive effect on BWEF's career outcomes.

Immediate next steps include pilot testing the items and performing an item analysis to ascertain each item's quality. This will immediately be followed disseminating the instrument to a national pool of Black women engineering faculty to validate the constructs and empirically test relationships between the factors and outcomes. Such insights are useful to starting a more nuanced intercontinental dialogue that will have implications for broadening participation across all levels of engineering education.

\section{Pilot Study}

\section{Item Development}

Using Messick's theory of instrument development $[9,10]$ as a methodological framework, the long-term aim of this study is to develop the Faculty Experiences \& Outcomes Multidimensional Scale (FEOMS)-- a valid and reliable instrument that examines the influence of mentoring, organizational climate, incivility, and role expectations on the career outcomes and jobs satisfaction of engineering faculty, especially women of color. This study includes the results of a pilot study toward this end. FOEMS is a compilation of items pulled from existing instruments that measure the four aforementioned factors (e.g., [4-8]) and tweaked for studying these phenomena in an academic context. While the complete survey included a combination of item formats (e.g., fill in the blank, inserting a number of hours dedicated to routine tasks), only the Likert items will be discussed in this study. Since the original items were on a 5-point scale, all items included in FOEMS were also placed on the same 5-point Likert scale, with anchors ranging from Strongly Disagree to Strongly Agree.

\section{Data Collection \& Data Analysis}

FEOMS was sent to engineering faculty at several institutions via an email including a Qualtrics ${ }^{\circledR}$ link. One hundred eleven (111) participants responded. However, only 27 participants completed the survey. An item analysis was performed to determine which survey items showed promise for completing another round of data collection with a larger sample. jMetrik is the statictical package that was used to analyze the data. The next section includes the output of the jMetrik item analysis. The bold items indicate those that would be retained in the next round of data collection due to its strong performance during this pilot study. This determination is based on two pieces of information: statistics in the Item Difficulty and Item Discrimination columns. Since the overall Difficulty ranges from $0-3, \mathrm{I}$ look for a number that is positive, at least 0.5 , preferably close to 1.5 , and includes a number larger than zero for all of the options. Similarly, Discrimination statistics that are positive and are above $0.2-0.3$ are ideal 
The overall Cronbach's $\alpha=0.8656$, which indicates a good reliability of the items. Table 1 includes the results of the item analysis associated with the overall score for each item. Thirty-five (35) of out the 49 items show promise based on the item difficulty and item discrimination. For all of the items, the item difficulty was at least 0.5 , but none of the items were close to the 1.5 ideal.

Table 1. Item Analysis

\begin{tabular}{|c|c|c|c|c|}
\hline $\begin{array}{l}\text { Item } \\
\text { Number }\end{array}$ & Item Content & $\begin{array}{l}\text { Item } \\
\text { Difficulty }\end{array}$ & Std. Dev. & $\begin{array}{l}\text { Item } \\
\text { Discrimination }\end{array}$ \\
\hline \multicolumn{5}{|c|}{$\begin{array}{l}\text { Item Stem: With your mentor in mind, indicate the extent to which you agree with the following } \\
\text { statements... }\end{array}$} \\
\hline Q1_1 & I perceive myself as coachable. & 4.2963 & 0.6068 & 0.0391 \\
\hline Q1_2 & $\begin{array}{l}\text { My mentor encourages me to develop } \\
\text { strategies for managing my life while } \\
\text { pursuing my career goals }\end{array}$ & 3.222 & 0.8473 & 0.5924 \\
\hline Q1_3 & $\begin{array}{l}\text { I have received help in developing } \\
\text { concrete strategies to achieve my } \\
\text { career goals. }\end{array}$ & 3.222 & 0.8473 & 0.4055 \\
\hline Q1_4 & $\begin{array}{l}\text { I have been encouraged to discuss } \\
\text { problems I face in my career. }\end{array}$ & 3.1852 & 0.9214 & 0.5173 \\
\hline Q1_5 & $\begin{array}{l}\text { I have been made aware of a variety of } \\
\text { academic career paths }\end{array}$ & 3.1111 & 1.0860 & 0.2922 \\
\hline Q1_6 & $\begin{array}{l}\text { I have been encouraged to express my } \\
\text { honest feelings concerning my } \\
\text { experiences in the department. }\end{array}$ & 3.2963 & 1.0309 & 0.6499 \\
\hline Q1_7 & $\begin{array}{l}\text { My mentor provides me with guidance } \\
\text { on attainable academic objectives. }\end{array}$ & 3.2593 & 0.9842 & 0.6959 \\
\hline Q1_8 & $\begin{array}{l}\text { I have discussed the importance of } \\
\text { developing a realistic view of my } \\
\text { academic career with my mentor. }\end{array}$ & 3.1111 & 0.9740 & 0.4739 \\
\hline Q1_9 & $\begin{array}{l}\text { My mentor asks me probing questions } \\
\text { so that I can reflect on my academic } \\
\text { career PROGRESS }\end{array}$ & 2.6667 & 0.9608 & 0.5784 \\
\hline Q1_10 & $\begin{array}{l}\text { My mentor provides me with practical } \\
\text { suggestions for improving my career } \\
\text { performance. }\end{array}$ & 3.4074 & 0.9711 & 0.5484 \\
\hline Q1_11 & $\begin{array}{l}\text { My meetings with my mentor are } \\
\text { arranged such that we are rarely } \\
\text { interrupted }\end{array}$ & 2.9630 & 1.0554 & 0.4316 \\
\hline Q1_12 & $\begin{array}{l}\text { My mentor provides me with support } \\
\text { when I am emotionally unsettled. }\end{array}$ & 3.1111 & 0.8916 & 0.4242 \\
\hline Q1_13 & $\begin{array}{l}\text { My mentor asks me probing questions } \\
\text { so that I can reflect on my academic } \\
\text { career PLANS }\end{array}$ & 2.8519 & 0.9885 & 0.7403 \\
\hline Q1_14 & $\begin{array}{l}\text { My mentor expresses confidence in my } \\
\text { ability to succeed in the pursuit of my } \\
\text { career goals }\end{array}$ & 3.8519 & 0.9885 & 0.6446 \\
\hline Q1_15 & $\begin{array}{l}\text { My mentor encourages me to use them } \\
\text { as a sounding board to explore my } \\
\text { ideas }\end{array}$ & 3.4815 & 1.0141 & 0.5408 \\
\hline Q1_16 & $\begin{array}{l}\text { My mentor uses their personal } \\
\text { experiences to provide insights } \\
\text { relevant to my concerns }\end{array}$ & 3.7778 & 0.9337 & 0.5991 \\
\hline
\end{tabular}




\begin{tabular}{|c|c|c|c|c|}
\hline Q1_17 & $\begin{array}{l}\text { My mentor helps me develop coping } \\
\text { strategies when my career goals were } \\
\text { not achieved }\end{array}$ & 2.8889 & 0.7511 & 0.3938 \\
\hline Q1_18 & $\begin{array}{l}\text { My mentor encourages me to consider } \\
\text { training opportunities that will help } \\
\text { me reach my professional goals }\end{array}$ & 3.2963 & 0.9121 & 0.4119 \\
\hline \multicolumn{5}{|c|}{$\begin{array}{l}\text { Item Stem: With your current department in mind, indicate the extent to which you agree with } \\
\text { the following statements... }\end{array}$} \\
\hline Q2_1 & $\begin{array}{l}\text { People tend to get along with each } \\
\text { other }\end{array}$ & 4.0370 & $\mathbf{0 . 5 1 7 5}$ & 0.3422 \\
\hline Q2_2 & $\begin{array}{l}\text { People take a personal interest in one } \\
\text { another }\end{array}$ & 3.8148 & 0.6225 & 0.6913 \\
\hline Q2_3 & $\begin{array}{l}\text { I feel like I have a lot in common my } \\
\text { colleagues }\end{array}$ & 3.4815 & $\mathbf{0 . 7 5 3 0}$ & 0.3506 \\
\hline Q2_4 & $\begin{array}{l}\text { I can count on my colleagues to keep } \\
\text { the things I tell him/her confidential }\end{array}$ & 3.4815 & $\mathbf{0 . 7 5 3 0}$ & 0.3996 \\
\hline Q2_5 & $\begin{array}{l}\text { My colleagues follow through on } \\
\text { commitments made to me }\end{array}$ & 3.5556 & 0.8473 & 0.2071 \\
\hline Q2_6 & $\begin{array}{l}\text { My colleagues are not likely to give me } \\
\text { bad advice }\end{array}$ & 3.5926 & 0.5724 & 0.0821 \\
\hline Q2_7 & $\begin{array}{l}\text { I have too much work to do with } \\
\text { insufficient time to do it }\end{array}$ & 3.9630 & 0.8979 & 0.1628 \\
\hline Q2_8 & My department is a relaxed place to work & 3.2963 & 0.7240 & 0.0188 \\
\hline Q2_9 & $\begin{array}{l}\text { At home, I dread hearing the telephone } \\
\text { ring because it might be a work-related } \\
\text { problem }\end{array}$ & 2.4444 & 0.6980 & -0.0459 \\
\hline Q2_10 & I feel like I have never had a day off & 3.1481 & 1.0991 & 0.1274 \\
\hline Q2_11 & $\begin{array}{l}\text { At work, too many colleagues get } \\
\text { "burned out" by the demands of their job }\end{array}$ & 3.3333 & 0.6794 & 0.0337 \\
\hline Q2_12 & $\begin{array}{l}\text { I can count on a "pat on the back" } \\
\text { when I perform well } \\
\end{array}$ & 3.5185 & 0.8490 & 0.2432 \\
\hline Q2_13 & $\begin{array}{l}\text { The only time I hear about my } \\
\text { performance is when I make a mistake }\end{array}$ & 2.6296 & 0.6877 & -0.2995 \\
\hline Q2_14 & $\begin{array}{l}\text { My department head communicates } \\
\text { my strengths to me }\end{array}$ & $\mathbf{3 . 3 3 3 3}$ & 0.7845 & 0.3894 \\
\hline Q2_15 & $\begin{array}{l}\text { The expectations for my job are } \\
\text { reasonable }\end{array}$ & 3.2222 & 0.7511 & -0.1264 \\
\hline Q2_16 & $\begin{array}{l}\text { My department head is quick to } \\
\text { recognize good performance }\end{array}$ & 3.4444 & 0.8006 & 0.5056 \\
\hline Q2_17 & $\begin{array}{l}\text { My department head uses my work as } \\
\text { an example of what to do }\end{array}$ & 3.4444 & 0.6980 & 0.4919 \\
\hline Q2_18 & $\begin{array}{l}\text { My department head is not likely to } \\
\text { give me a hard time }\end{array}$ & 3.8148 & 0.7357 & 0.4509 \\
\hline Q2_19 & $\begin{array}{l}\text { I can count on a fair evaluation from } \\
\text { my department head }\end{array}$ & 3.8889 & 0.6405 & 0.3469 \\
\hline Q2_20 & $\begin{array}{l}\text { My department head does not play } \\
\text { favorites }\end{array}$ & 3.6667 & 0.9199 & 0.2608 \\
\hline \multicolumn{5}{|c|}{ Civility Items } \\
\hline Q3_1 & My colleagues treat me with respect & 4.2963 & $\mathbf{0 . 7 7 5 3}$ & 0.3681 \\
\hline Q3_2 & My colleagues treat me with dignity & 4.4074 & 0.6360 & 0.3008 \\
\hline Q3_3 & My colleagues treat me politely & 4.4074 & 0.5724 & 0.1895 \\
\hline Q3_4 & My colleagues are pleasant to me & 4.2963 & 0.6688 & 0.2934 \\
\hline
\end{tabular}




\begin{tabular}{|c|c|c|c|c|}
\hline Q3_5 & My colleagues treat me with civility & 4.3704 & 0.5649 & 0.1885 \\
\hline \multicolumn{5}{|c|}{$\begin{array}{l}\text { Item Stem: With the LAST MONTH in mind, indicate the extent to which you agree with the } \\
\text { following statements... }\end{array}$} \\
\hline Q4_1 & $\begin{array}{l}\text { I have felt unable to control the important } \\
\text { things in my life }\end{array}$ & 2.7407 & 1.1298 & 0.0833 \\
\hline Q4_2 & I have felt nervous or stressed & 3.7407 & 1.1298 & 0.1589 \\
\hline Q4_3 & I have felt that things were going my way & 3.3704 & 0.7415 & 0.0161 \\
\hline Q4_4 & $\begin{array}{l}\text { I found that I could cope with all the } \\
\text { things I had to do }\end{array}$ & 3.2963 & 0.9121 & -0.0903 \\
\hline Q4_5 & I have not felt that I was on top of things & 3.1852 & 0.8338 & -0.0336 \\
\hline Q4_6 & $\begin{array}{l}\text { I have been angered because of things } \\
\text { that were outside of my control }\end{array}$ & 2.7778 & 0.8916 & 0.2612 \\
\hline
\end{tabular}

Table 2. TEST LEVEL STATISTICS

Number of Items $=49$

Number of Examinees $=27$

Skewness $=-0.0688$

Kurtosis $=-0.3691$

$\mathrm{KR} 21=2.9253$

Table 3. RELIABILITY ANALYSIS

\begin{tabular}{|c|c|c|c|}
\hline Method & Estimate & $95 \%$ Conf. Int. & SEM \\
\hline Guttman's L2 & 0.8933 & $(0.8268,0.9434)$ & 4.9570 \\
\hline Coefficient Alpha & 0.8658 & $(0.7821,0.9288)$ & 5.5601 \\
\hline Feldt-Gilmer & 0.8778 & $(0.8015,0.9352)$ & 5.3059 \\
\hline Feldt-Brennan & 0.8750 & $(0.7971,0.9337)$ & 5.3656 \\
\hline Raju's Beta & 0.8658 & $(0.7821,0.9288)$ & 5.5601 \\
\hline
\end{tabular}

In short, most of the items associted with mentoring and organizational climate performed well while the items associated with incivility in the workplace did not perform as well. In light of these results, there are two immediate next steps for the development of FEOMS. One, the items that did not perform well will be revised. Secondly, the survey will be disseminated to a larger pool of potential participants such that the survey development can continue.

Once the FEOMS is fully developed, it has the potential to be useful to both individual faculty members and to adminstrators. Invidual faculy may use it to the make connections between their current reality at any given time and their career goals, and make data-driven decisions about areas of their workplace experiences that need to be changed in order to realize different career outcomes. Furthermore, administrators may be able to use the aggregrate results from a group of faculty within their unit (deparment, college, etc.) to understand and influence the work environment they oversee, especially as it relates to mentoring, organizational climate, and civility. Collectively, this can lead to better workplace experiences and ultimately better career outcomes for underrepresented engineering faculty.

\section{References}


[1] National Academy of Sciences, National Academy of Engineering, and Institute of Medicine. (2007). Beyond Bias and Barriers: Fulfilling the Potential of Women in Academic Science and Engineering. Washington, DC: The National Academies Press. https://doi.org/10.17226/11741

[2] Berry, C. A., Cox, M. F., \& Main, J. B. (2014). Women of Color Engineering Faculty: An examination of the experiences and the numbers. In ASEE Annual Conference, Indianapolis, Indiana. Retrieved from https://peer. asee. org/23314.

[3] Ross, M. M. S., \& Fletcher, M. T. L. (2015). African American Women in the Academe: A Comprehensive Literature Re-view through the lens of Intersectionality. age, 26, 1.

[4] Smith, J. W., Smith, W. J., \& Markham, S. E. (2000). Diversity issues in mentoring academic faculty. Journal of Career Development, 26(4), 251-262.

[5] Porath, C. L., Gerbasi, A., \& Schorch, S. L. (2015). The effects of civility on advice, leadership, and performance. Journal of Applied Psychology, 100(5), 1527-1541.

https://doi.org/10.1037/apl0000016

[6] Lindfelt, T. A., Ip, E. J., \& Barnett, M. J. (2015). Survey of career satisfaction, lifestyle, and stress levels among pharmacy school faculty. American Journal of Health-System Pharmacy, 72(18), 15731578. https://doi.org/10.2146/ajhp140654

[7] Wood, O. R. (1976). A Research Project: Measuring Job Satisfaction of the Community College Staff. Community College Review, 56-64. https://doi.org/10.1177/009155217600300309

[8] McMurray, A., \& Scott, D. (2013). Determinants of organizational climate for academia. Higher Education Research and Development, 32(6), 960-974. https://doi.org/10.1080/07294360.2013.806446

[9] Messick, S. (1995). Validity of psychological assessment: Validation of inferences from persons' responses and performances as scientific inquiry into score meaning. The American psychologist, 50(9), $741-749$

[10] Messick, S. (1996). Validity and washback in language testing. Language Testing, 13(3), 241256.

[11] Gregory, S. T. (1999). Black Women in the Academy: The Secrets to Success and Achievement. Lanham: University Press of America, Inc.

[12] Stanley, C.A. (Ed.). (2006). Faculty of color: Teaching in predominantly White colleges and universities. Bolton, MA: Anker Publishers. 